\title{
IDENTIFIKASI PRODUK UNGGULAN SUBSEKTOR TANAMAN PERKEBUNAN SEMUSIM SETIAP KECAMATAN DI KABUPATEN JOMBANG
}

\author{
${ }^{1}$ Andi Firmansah, ${ }^{2}$ Rohmat Hidayat, ${ }^{3}$ Nerisa Agnesia. \\ Program Studi Agribisnis Fakultas Pertanian Universitas KH. A. Wahab Hasbullah \\ andifirmansyah212@gmail.com
}

\begin{abstract}
ABSTRAK
Penelitian ini bertujuan untuk mengetahui subsektor tanaman perkebunan semusim yang menjadi produk unggulan setiap kecamatan di Kabupaten Jombang. Penelitian ini dilaksanakan selama bulan Juni hingga Agustus tahun 2020. Metode pengumpulan data pada penelitian ini menggunakan kualitatif deskriptif. Data sekunder diambil dari sumber terkait dan dihitung menggunakan analisa location quotient (LQ). Hasil analisa LQ luas lahan dan produksi setiap kecamatan dideskripsikan dan dilakukan identifikasi untuk mengetahui nilai yang mempengaruhi LQ. Produk perkebunan semusim di Kabupaten Jombang selama periode tahun 2014-2018 adalah tanaman tebu dan tembakau. Kecamatan yang memiliki nilai basis produksi dan luas lahan tanaman tebu di Kabupaten Jombang selama periode tahun diatas adalah Kecamatan Bandar Kedung Mulyo, Perak, Gudo, Diwek, Ngoro, Mojowarno, Bareng, Wonosalam, Mojoagung, Sumobito, Peterongan, Jombang, Jogoroto, Peterongan, Tembelang, Megaluh Kesamben dan Ngusikan. Sedangkan untuk tanaman tembakau kecamatan yang memiliki nilai basis secara basis dan luas lahan di Kabupaten Jombang adalah Kecamatan Kudu, Ngusikan, Ploso, Kabuh dan Plandaan.
\end{abstract}

Kata kunci: Basis, LQ, Perkebunan Semusim

\section{PENDAHULUAN}

Jawa Timur berkontribusi paling besar dalam Produk Domestik Regional Bruto pertanian serta berkontribusi terbesar ketiga dalam Produk Domestik Regional Bruto perkebunan dari tahun 2010-2015. Hal ini dikarenakan provinsi tersebut yang mempunyai potensial dalam pertanian dan perkebunan. Jawa Timur memiliki beberapa tanaman dalam perkebunan yaitu.cengkeh, jambu mete, kakao, kapas, karet, kelapa, kopi, lada, nilam, pala, tebu, tembakau dan teh. Salah satu produk unggulan Provinsi Jawa Timur berasal dari sub sektor tanaman perkebunan semusim adalah tanaman tebu dan tembakau.

Kabupaten Jombang merupakan salah satu penghasil tebu dan tembakau yang cukup besar di wilayah Jawa Timur (BPS Provinsi Jawa Timur, 2018). Produksi tanaman tebu di Kabupaten Jombang menduduki peringkat 4 terbanyak dari seluruh Kabupaten di Provinsi Jawa Timur. Produksi tanaman tebu di Kabupaten Jombang pada periode tahun 2013-2017 rata-rata yaitu 255.036 ton. Selama periode tahun 2013-2017 angka produksi di Kabupaten Jombang yaitu pada tahun 2013 dengan produksi mencapai 68.462 ton. Sedangkan untuk produksi tembakau kabupaten Jombang menduduki peringkat 6 dari seluruh kabupaten di provinsi Jawa Timur. Pada tahun 2011-2015 angka produksi tembakau terbesar di Kabupaten Jombang yaitu pada tahun 2014 dengan produksi mencapai 7.110 ton. Berdasarkan data tersebut di atas, Kabupaten Jombang mempunyai keunggulan dan produktifitas yang berbeda-beda dalam mengasilkan suatu produk pertanian terutama produk subsektor perkebunan semusim. Hal tersebut tidak terlepas dari potensi - potensi yang berada di kecamatan wilayah Jombang 
terutama komoditi perkebunan semusim, yang mendukung Kabupaten Jombang sebagai bagian penghasil komoditi perkebunan semusim di Jawa Timur. Oleh karena itu, peneliti sangat tertarik untuk membahas masalah tersebut dengan memberi judul "Analisa Identifikasi Produk Unggulan Sub Sektor Tanaman Perkebunan Semusim Setiap Kecamatan di Kabupaten Jombang"

\section{METODE PENELITIAN}

Tempat dan Waktu Penelitian. Kegiatan penelitian pelaksanaan penelitian serta pengambilan data ini dilakukan di Kabupaten Jombang pada bulan Juni Agustus 2020. Penelitian ini bersifat kualitatif deskriptif yang mana penelitian ini menggambarkan kondisi subsektor tanaman perkebunan semusim masingmasing kecamatan di wilayah Kabupaten Jombang

Jenis dan Sumber Data. Dengan mengambil data hasil produksi (ton) atau luas lahan panen (ha) sub sektor tanaman perkebunan semusim dari dinas terkait untuk diukur dengan data total produksi (ton) dan total luas lahan pertanian (ha) masing-masing kecamatan di kabupaten Jombang. Data dari dinas pertanian terkait serta sumber publikasi atau website yang mendukung diperlukan untuk mengukur nilai basis serta faktor-faktor yang mempengaruhi sub sektor perkebunan semusim serta hasil produksi dan luas lahan pada periode tahun 2014-2018 di masing-masing wilayah di kabupaten Jombang.

Tempat dan Waktu Penelitian. Kegiatan penelitian pelaksanaan penelitian serta pengambilan data ini dilakukan di Kabupaten Jombang pada bulan Juni Agustus 2020. Penelitian ini bersifat kualitatif deskriptif yang mana penelitian ini menggambarkan kondisi subsektor tanaman perkebunan semusim masingmasing kecamatan di wilayah Kabupaten Jombang.

\section{Metode Pengumpulan Data}

Jenis data yang digunakan adalah jenis data sekunder, yaitu data yang dikumpulkan oleh lembaga pengumpul data dan dipublikasikan kepada masyarakat pengguna data. Adapun data yang diperlukan dalam penelitian ini yaitu:

1. Data hasil produksi (ton) atau luas lahan panen (ha) sub sektor tanaman perkebunan semusim tahun 2014-2018.

2. Data total produksi (ton) dan luas lahan (ha) perkebunan masing-masing kecamatan di kabupaten Jombang tahun 2014-2018.

3. Data sekunder lainnya yang masih ada kaitannya dengan tujuan penelitian ini.

\section{Analisis Data}

Analisis location quotient (LQ) digunakan untuk melihat komoditas-komoditas unggul dari beberapa sektor yang ada di wilayah Kabupaten Jombang serta melihat subsektor tanaman perkebunan semusim yang paling unggul di wilayah Kabupaten Jombang baik dari konteks luas areal maupun produksi. Rumus dari location quotient itu sendiri untuk mengetahui komoditas unggulan berdasarkan Tanjung (2017) adalah:

di mana:

$$
L Q=\frac{p i / p t}{P i / P t}
$$

pi : Luas areal/produksi sub sektor i tingkat kecamatan

$p t$ : Total luas luas areal sub sektor i tingkat kabupaten

$P i$ : Jumlah luas areal/produksi sub sektor perkebunan 
$P t:$ Total jumlah luas areal/produksi sub sektor perkebunan

\section{HASIL DAN PEMBAHASAN}

Subsektor perkebunan di Kabupaten Jombang memiliki hasil produksi dan luas lahan yang berbeda-beda, sektor perkebunan terbagi menjadi 2 yaitu subsektor perkebunan tahunan meliputi kakao, kelapa, kopi dan cengkeh. Subsektor perkebunan semusim yang meliputi tebu dan tembakau. Setiap kecamatan dengan karakteristiknya memiliki jumlah produksi dan luas lahan yang berbeda. Dalam penelitian ini perhitungan jumlah nilai produksi dan luas lahan panen dari subsektor perkebunan semusim yaitu tanaman tebu dan tembakau di masing-masing kecamatan akan dibandingkan dengan seluruh jumlah produksi dan nilai luas lahan seluruh sektor perkebunan kecamatan yang ada di Kabupaten Jombang. Penyebab besar kecilnya nilai LQ pada salah satu sub sektor perkebunan semusim di suatu wilayah dapat disebabkan oleh beberapa faktor, seperti besarmya luas lahan, banyaknya produksi, persaingan kompetitif komoditas perkebunan lain dan kondisi geografis. Berikut merupakan data time series nilai LQ dan rata-rata produksi serta luas lahan masingmasing kecamatan dari tahun 2014-2018 sub sektor perkebunan semusim di kabupaten Jombang.

Berikut Nilai LQ Tanaman Tebu menurut produksi dan luas lahan di setiap kecamatan wilayah kabupaten Jombang tahun 2014 - 2018 yang tertuang dalam tabel 1 dan 2 di bawah ini.

Tabel 1. Nilai LQ Tanaman Tebu Menurut Produksi dan Luas Lahan di setiap Kecamatan Wilayah Kabupaten Jombang Tahun 2014-2018

\begin{tabular}{|c|c|c|c|c|c|c|c|c|c|c|}
\hline \multirow{3}{*}{ Kecamatan } & \multicolumn{10}{|c|}{ Nilai LQ Tebu } \\
\hline & \multicolumn{5}{|c|}{ Produksi (ton) } & \multicolumn{5}{|c|}{ Luas Lahan (Ha) } \\
\hline & 2014 & 2015 & 2016 & 2017 & 2018 & 2014 & 2015 & 2016 & 2017 & 2018 \\
\hline BK. Mulyo & 1,07 & 1,06 & 1,00 & 8,51 & 1,01 & 1,32 & 1,21 & 1,00 & 1,91 & 1,98 \\
\hline Perak & 1,07 & 1,06 & 1,00 & 8,51 & 1,01 & 1,74 & 1,56 & 1,00 & 1,91 & 1,98 \\
\hline Gudo & 1,07 & 1,06 & 1,00 & 8,51 & 1,01 & 1,71 & 1,55 & 1,00 & 1,91 & 1,98 \\
\hline Diwek & 1,07 & 1,06 & 1,00 & 8,49 & 1,01 & 1,72 & 1,55 & 1,00 & 1,90 & 1,98 \\
\hline Ngoro & 1,07 & 1,06 & 1,00 & 8,45 & 1,01 & 1,68 & 1,55 & 1,00 & 1,89 & 1,96 \\
\hline Mojowarno & 1,07 & 1,06 & 1,00 & 8,46 & 1,01 & 1,54 & 1,46 & 1,00 & 1,89 & 1,98 \\
\hline Bareng & 1,07 & 1,06 & 1,00 & 5,74 & 1,01 & 1,42 & 1,04 & 1,00 & 1,20 & 1,48 \\
\hline Wonosalam & 1,04 & 1,04 & 1,00 & 1,80 & 1,00 & 0,29 & 0,39 & 1,00 & 0,28 & 0,29 \\
\hline Mojoagung & 1,07 & 1,06 & 1,00 & 8,49 & 1,01 & 1,66 & 1,55 & 1,00 & 1,91 & 1,98 \\
\hline Sumobito & 1,07 & 1,06 & 1,00 & 8,08 & 1,01 & 1,50 & 1,54 & 1,00 & 1,80 & 1,98 \\
\hline Jogoroto & 1,07 & 1,06 & 1,00 & 8,51 & 1,01 & 1,61 & 1,54 & 1,00 & 1,91 & 1,98 \\
\hline Peterongan & 1,07 & 1,06 & 1,00 & 8,51 & 1,01 & 1,54 & 1,42 & 1,00 & 1,91 & 1,98 \\
\hline Jombang & 1,07 & 1,06 & 1,00 & 8,41 & 1,01 & 1,72 & 1,54 & 1,00 & 1,88 & 1,98 \\
\hline Megaluh & 0,99 & 1,01 & 1,00 & 8,51 & 1,01 & 0,15 & 0,20 & 1,00 & 1,91 & 1,98 \\
\hline Tembelang & 1,07 & 1,06 & 1,00 & 8,00 & 1,01 & 1,35 & 1,47 & 1,00 & 1,79 & 1,98 \\
\hline Kesamben & 1,07 & 1,06 & 1,00 & 8,45 & 1,01 & 1,62 & 1,55 & 1,00 & 1,90 & 1,98 \\
\hline Kudu & 0,89 & 0,83 & 0,98 & 0,40 & 0,96 & 0,77 & 0,69 & 1,00 & 0,79 & 0,46 \\
\hline Ngusikan & 0,84 & 0,78 & 1,00 & 3,65 & 1,01 & 0,52 & 0,44 & 1,00 & 1,74 & 1,53 \\
\hline Ploso & 0,10 & 0,68 & 0,94 & 0,03 & 0,83 & 0,03 & 0,38 & 0,99 & 0,09 & 0,13 \\
\hline Kabuh & 0,21 & 0,36 & 0,87 & 0,02 & 0,75 & 0,07 & 0,06 & 0,98 & 0,06 & 0,08 \\
\hline Plandaan & 0,78 & 0,46 & 0,97 & 0,16 & 0,91 & 0,47 & 0,42 & 1,00 & 0,45 & 0,26 \\
\hline
\end{tabular}


Sumber : Data diolah, 2020

Tanaman tebu dapat tumbuh di daerah dataran rendah hingga dataran tinggi, hingga pada ketinggian 1.400 meter di atas permukaan laut (dpl)(Dinas Pertanian, 2020). Tetapi pada ketinggian mulai 1.200 mdpl pertumbuhan tanaman tersebut akan lambat. Adapun curah hujan yang optimum untuk tanaman tebu adalah $1.500-2.500 \mathrm{~mm}$ per tahun dengan hujan tersebar merata. Produksi yang maksimum dicapai pada kondisi yang memiliki perbedaan curah hujan yang ekstrim antara musim hujan dan musim kemarau. Suhu yang baik untuk tanaman tebu berkisar antara $24^{\circ} \mathrm{C}$ hingga $30^{\circ} \mathrm{C}$, dengan kelembaban berkisar $65-70 \%$, dan $\mathrm{pH}$ tanah 5,5 - 7,0. Setiap kecamatan di wilayah Kabupaten Jombang mempunyai kondisi geografis dan karakteristik lahan pertanian yang berbeda-beda, sehingga berpengaruh terhadap produk pertanian yang menjadi mayoritas di wilayah tersebut Nilai LQ tanaman tebu berdasarkan produksi mencapai puncaknya pada tahun 2017 di 17 kecamatan, meningkat dari tahun sebelumnya 2016 dengan rata-rata 1,0 menjadi 8,0 setiap kecamatan. Faktor tersebut dipengaruhi oleh menurunnya produksi tanaman tebu pada masing-masing kecamatan di Kabupaten Jombang, sehingga pembagian terhadap konstanta atau nilai tetap yaitu seluruh jumlah produksi komoditas perkebunan pada tahun tersebut berpengaruh terhadap nilai hasil LQ menjadi lebih besar.

Tabel 2. Rata-Rata Produksi, Luas Lahan dan Nilai LQ Tanaman Tebu di Kabupaten Jombang Tahun 2014-2018

\begin{tabular}{lcc|cc}
\hline \multirow{2}{*}{ Kecamatan } & \multicolumn{3}{c}{ Rata-Rata Produksi, Luas Lahan \& LQ Tebu } \\
\cline { 2 - 5 } (ton) & LQ Produksi & $\begin{array}{c}\text { Luas Lahan } \\
\text { (Ha) }\end{array}$ & $\begin{array}{c}\text { LQ } \\
\text { Luas Lahan }\end{array}$ \\
\hline B. Kedung Mulyo & $50.385,52$ & 2,53 & $16.857,90$ & 1,48 \\
Perak & $89.717,81$ & 2,53 & $42.813,46$ & 1,64 \\
Gudo & $188.664,62$ & 2,53 & $86.961,46$ & 1,63 \\
Diwek & $493.929,52$ & 2,53 & $222.637,95$ & 1,63 \\
Ngoro & $443.844,17$ & 2,52 & $213.840,02$ & 1,62 \\
Mojowarno & $228.624,15$ & 2,52 & $151.587,92$ & 1,58 \\
Bareng & $321.729,04$ & 1,98 & $211.151,23$ & 1,23 \\
Wonosalam & $123.783,93$ & 1,18 & $97.888,30$ & 0,45 \\
Mojoagung & $259.910,67$ & 2,53 & $211.085,79$ & 1,62 \\
Sumobito & $221.589,26$ & 2,44 & $151.771,02$ & 1,56 \\
Jogoroto & $147.649,79$ & 2,53 & $77.321,96$ & 1,61 \\
Peterongan & $82.498,61$ & 2,53 & $29.849,82$ & 1,57 \\
Jombang & & 2,51 & & 1,62 \\
& & & & \\
\hline
\end{tabular}




\begin{tabular}{lll|ll} 
& $71.711,44$ & & $27.073,12$ & \\
Megaluh & $12.420,57$ & 2,50 & $4.621,45$ & 1,05 \\
Tembelang & $29.567,48$ & 2,43 & $19.877,28$ & 1,52 \\
Kesamben & $186.703,93$ & 2,52 & $128.985,23$ & 1,61 \\
Kudu & $104.277,40$ & 0,81 & $70.865,83$ & 0,74 \\
Ngusikan & $139.702,64$ & 1,46 & $106.499,35$ & 1,05 \\
Ploso & $27.448,79$ & 0,52 & $18.126,88$ & 0,33 \\
Kabuh & $41.676,21$ & 0,44 & $17.254,46$ & 0,25 \\
Plandaan & $26.105,71$ & 0,65 & $12.544,64$ & 0,52 \\
\hline
\end{tabular}

Sumber : Data diolah, 2020

Kecamatan Bandar Kedung Mulyo menjadi basis produksi dan luas lahan untuk sektor tebu di Kabupaten Jombang. Menurut BPS Jombang (2019), Kecamatan Bandar Kedung Mulyo Dalam Angka Tahun 2019, pada tahun 2018 lahan pertanian di Kecamatan Bandar Kedung Mulyo lebih didominasi oleh sektor tanaman pangan, hal tersebut dapat diketahui dari jumlah nilai luas lahan padi yang mencapai $4.500 \mathrm{Ha}$ dan Jagung $1,189 \mathrm{Ha}$, sedangkan untuk tanaman perkebunan hanya terdapat tanaman tebu dengan luas lahan $171 \mathrm{Ha}$. Rata-rata perhitungan nilai basis tanaman tebu di Kecamatan Bandar Kedung Mulyo pada tahun 2014-2018 memiliki produksi yaitu 50.385,52 dengan nilai LQ 2,53 dan luas lahan $16.857,90 \mathrm{Ha}$ dengan nilai LQ 1,48. Walaupun tidak mempunyai produksi serta luas lahan yang cukup besar, nilai $L Q>1$ produksi dan luas lahan tersebut lebih dipengaruhi oleh rendahnya produk pesaing tanaman perkebunan lain di wilayah tersebut. Adapun produk tanaman perkebunan lain di Kecamatan Bandar Kedung Mulyo adalah kelapa pada tahun 2014 dengan nilai produksi 35,46 ton serta luas lahan $41,00 \mathrm{Ha}$, dan di tahun 2015 dengan produksi 35,46 ton dan luas lahan $36,00 \mathrm{Ha}$.

Kecamatan Perak pada tahun 2014-2018 mempunyaii rata-rata produksi tanaman tebu 89,717.81 ton dengan nilai LQ 2.53 dan luas lahan 42,813.46 $\mathrm{Ha}$ dengan nilai LQ 1.64. Berdasarkan data BPS Kabupaten Jombang Kecamatan Perak Dalam Angka Tahun 2019, pada tahun 2018 luas lahan di kecamatan Perak lebih besar digunakan untuk sektor tanaman pangan yaitu padi dengan luas lahan 4.887 Ha dan jagung dengan luas lahan 806,9 Ha, sedangkan untuk tanaman tebu luas lahan hanya $121 \mathrm{Ha}$. Nilai basis tanaman tebu di Kecamatan Perak lebih dipengaruhi dari tidak adanya produksi tanaman perkebunan lain. Data perkebunan dari tahun 2014-2018 tidak terdapat tanaman perkebunan seperti tembakau, kakao, cengkeh, kelapa dan kopi, sehigga menjadikan tanaman tebu sebagai tanaman unggulan di wilayah terebut.

Kecamatan Gudo menjadi wilayah basis untuk produksi dan luas lahan tanaman tebu di Kabupaten Jombang. Nilai basis di kecamatan Gudo dipengaruhi oleh besarnya luas lahan dan produksi di wilayah tersebut. Pada tahun 2014-2019, kecamatan Gudo mempunyai rata-rata produksi tebu 188.664,62 ton dengan nilai LQ 2,53, dan luas lahan 86.961,46 Ha dengan nilai LQ 1,63. Tanaman perkebunan pesaing lainnya di kecamatan Gudo hanya 
terdapat tanaman Kelapa pada tahun 2016 dengan luas lahan 3,00 Ha dan produksi 0,59 ton.

Kecamatan Diwek pada tahun 2014-2018 mempunyai rata-rata produksi tanaman tebu yang cukup besar yaitu 493.929,52 dengan nilai LQ 2,53 dan ratarata luas lahan 222.637,95 dengan nilai LQ 1,63. Nilai basis LQ dipengaruhi oleh besarnya produksi dan luas lahan di wilayah tersebut. Tingginya produksi tebu di Kecamatan Diwek dipengaruhi oleh kondisi lahan di daerahnya. Berdasarkan data BPS Kabupaten Jombang Kecamatan Diwek Dalam Angka Tahun 2019, 20 wilayah kelurahan di kecamatan Diwek rata-rata mempunyai ketinggian 36,85 mdpl. Hal tersebut berpengaruh terhadap karakteristik tanaman tebu yang sangat baik untuk dibudidayakan pada ketinggian tidak lebih dari >1.200 mdpl.

Kecamatan Ngoro menjadi basis produksi serta luas lahan tanaman tebu di Kabupaten Jombang pada tahun 2014-2018. Kecamatan tersebut mempunyai rata-rata nilai produksi tanaman tebu sebesar $443.844,17$ ton dengan nilai LQ 2,52, dan rata-rata luas lahan 213.840,02 Ha dengan nilai LQ 1,62. Menurut BPS Kabupaten Jombang, luas kecamatan Ngoro yang mencapai 49,86 km², dan $59,8 \%$ merupakan lahan sawah dan $17 \%$ merupakan tegalan.

Kecamatan Mojowarno pada tahun 2014-2018 menjadi basis produksi serta luas lahan tanaman tebu di Kabupaten Jombang. Berdasarkan BPS Kabupaten Jombang, Kecamatan Mojowarno dalam angka tahun 2019, kecamatan tersebut mempunyai rata-rata nilai produksi tanaman tebu sebesar $228.624,15$ ton dengan nilai LQ 2,52 dan rata-rata luas lahan $151.587,92 \mathrm{Ha}$ dengan nilai $L Q 1,58$.

Kecamatan Bareng, produksi serta luas lahan tanaman tebu yang dimiliki menjadi sektor basis di Kabupaten Jombang pada tahun 2014-2018. Kecamatan Bareng memiliki rata-rata nilai produksi tanaman tebu sebesar 321.729,04 ton dengan nilai $L Q 1,93$ dan rata-rata luas lahan 211.151,23 Ha dengan nilai LQ 1,23. Walaupun nilai basis rata-rata $L Q$ produksi dan luas lahan yang lebih rendah dibanding nilai basis kecamatan lain di Kabupaten Jombang, akan tetapi berdasarkan data produksi dan luas lahan, Kecamatan Bareng memiliki angka yang cukup besar. Nilai LQ tersebut dipengaruhi oleh perhitungan pembagian produksi dan luas lahan oleh tanaman perkebunan lain yang ada di wilayah tersebut. Tanaman perkebunan lain yang berada di Kecamatan Bareng adalah tembakau, cengkeh, kopi, kelapa dan kakao.

Kecamatan Wonosalam di Kabupaten Jombang pada tahun 2014-2018 merupakan basis produksi tanaman tebu, akan tetapi untuk luas laham belum menjadi sektor basis. Kecamatan tersebut mempunyai rata-rata nilai produksi tanaman tebu sebesar $123.783,93$ ton dengan nilai $L Q 1,18$ dan rata-rata luas lahan $97,888.30 \mathrm{Ha}$ dengan nilai LQ 0,45 . Adanya nilai basis pada produksi tanaman tebu yang dimiliki oleh Kecamatan Wonosalam disebabkan oleh tingginya produksi tanaman tebu yang ada di wilayah tersebut. Sedangkan untuk luas lahan belum menjadi sektor basis, disebabkan oleh besanya penggunaan luas lahan oleh tanaman perkebunan tahunan yang ada di kecamatan Wonosalam.

Kecamatan Mojoagung menjadi basis produksi serta luas lahan tanaman tebu di kabupaten Jombang pada tahun 2014-2018. Kecamatan Mojoagung memiliki rata-rata nilai produksi tanaman tebu sebesar $443.844,17$ ton dengan nilai LQ 2,52 dan rata-rata luas lahan 213.840,02 Ha dengan nilai LQ 1,62. Pengaruh nilai basis LQ di kecamatan Mojoagung dipengaruhi oleh tanaman tebu merupakan tanaman perkebunan mayoritas di wilayah tersebut. Adapun tanaman perkebunan lain yang ada di Kecamatan Mojoagung pada tahun 20142018 adalah tanaman kelapaa. 
Kecamatan Sumobito menjadi basis produksi serta luas lahan tanaman tebu di Kabupaten Jombang pada tahun 2014-2018. Kecamatan tersebut mempunyai rata-rata nilai produksi tanaman tebu sebesar $221.589,26$ ton dengan nilai LQ 2,44 dan rata-rata luas lahan 151.771,02 Ha dengan nilai LQ 1,56. Penggunaan luas lahan di Kecamatan Sumobito mayoritas digunakan untuk sektor tanaman pangan dan sedikit untuk tanaman perkebunan. Perhitungan nilai basis di Kecamatan Sumobito dipengaruhi oleh tanaman tebu merupakan tanaman perkebunan unggulan yang ada di wilayah tersebut.

Kecamatan Jogoroto menjadi basis produksi serta luas lahan tanaman tebu di Kabupaten Jombang pada tahun 2014-2018. Kecamatan Jogoroto mempunyai rata-rata nilai produksi tanaman tebu sebesar $147.649,79$ ton dengan nilai LQ 2,53 dan rata-rata luas lahan 77,321.96 $\mathrm{Ha}$ dengan nilai LQ 1,61. Nilai basis di Kecamatan Jogoroto diperngaruhi oleh tanaman tebu merupakan tanaman perkebunan unggulan yang ada di wilayah tersebut. Adapun tanaman perkebunan lain yang ada di Kecamatan Jogoroto adalah tanaman kelapa yang produksinya berada pada tahun 2014 dengan angka produksi 42,54 ton dan 2015 dengan angka produksi 1,09 ton.

Kecamatan Peterongan pada tahun 2014-2018 menjadi basis produksi serta luas lahan tanaman tebu di Kabupaten Jombang. Kecamatan Peterongan mempunyai rata-rata nilai produksi tanaman tebu sebesar $82.498,61$ ton dengan nilai $L Q 2,52$ dan rata-rata luas lahan 29.849,82 Ha dengan nilai $L Q$ 1,62 Menurut BPS Jombang, Kecamatan Peterongan Dalam Angka Tahun 2019, pada tahun 2018 lahan pertanian di Kecamatan Peterongan lebih di dominasi oleh sektor tanaman pangan, hal tersebut dapat diketahui dari jumlah nilai luas lahan padi yang mencapai $3.146 \mathrm{Ha}$ dan jagung $1.430 \mathrm{Ha}$, sedangkan untuk tanaman perkebunan hanya terdapat tebu dengan luas lahan $165 \mathrm{Ha}$. Nilai LQ $>1$ pada nilai produksi dan luas lahan di Kecamatan Peterongan dipengaruhi oleh sedikitnya produk pesaing tanaman perkebunan lain di wilayah tersebut.

Kecamatan Jombang merupakan basis produksi serta luas lahan tanaman tebu di Kabupaten Jombang pada tahun 2014-2018. Kecamatan Jombang memiliki rata-rata nilai produksi tanaman tebu sebesar $71.711,44$ ton dengan nilai $L Q 2,51$ dan rata-rata luas lahan 27.073,12 Ha dengan nilai $L Q$ 1,62. Pengaruh nilai basis $L Q$ di Kecamatan Jombang dipengaruhi oleh tanaman tebu merupakan tanaman perkebunan unggulan di wilayah tersebut.

Kecamatan Megaluh menjadi basis produksi serta luas lahan tanaman tebu di Kabupaten Jombang pada tahun 2014-2018. Kecamatan Megaluh mempunyai rata-rata nilai produksi tanaman tebu sebesar $12.420,57$ ton dengan nilai $L Q 2,50$ dan rata-rata luas lahan $4.621,45 \mathrm{Ha}$ dengan nilai LQ 1,05. Menurut BPS Kabupaten Jombang, Kecamatan Megaluh Dalam Angka Tahun 2019 pada tahun 2018, penggunaan lahan pertanian di Kecamatan Megaluh yang merupakan area sawah, hampir 66,42 \% lebih di dominasi oleh sektor tanaman pangan, hal tersebut dapat diketahui dari jumlah nilai luas lahan padi yang mencapai $3.688 \mathrm{Ha}$. Sedangkan untuk tanaman perkebunan, hanya terdapat tebu dengan luas lahan $38 \mathrm{Ha}$. Walaupun terdapat tanaman perkebunan kelapa pada tahun 2014 dan 2015 di Kecamatan Megaluh, nilai basis di kecamatan produksi dan luas lahan di kecamatan Megaluh dipengaruhi oleh tanaman perkebunan tebu yang menjadi tanaman perkebunan unggulan di wilayah tersebut.

Kecamatan Tembelang pada tahun 2014-2018 mepunyai rata-rata produksi tanaman tebu $29.567,48$ ton dengan nilai LQ 2.43 dan luas lahan $19.877,28$ Ha dengan nilai LQ 1.52. Berdasarkan data BPS Kabupaten Jombang Kecamatan Tembelang Dalam Agka Tahun 2019, Pada tahun 2018 luas lahan di kecamatan Tembelang lebih besar digunakan untuk sektor tanaman pangan 
yaitu padi dengan luas lahan $4.579,54 \mathrm{Ha}$, jagung dengan luas lahan $817,73 \mathrm{Ha}$, kedelai dengan luas lahan 1.451,39 $\mathrm{Ha}$, sedangkan untuk tanaman tebu luas lahan hanya $58,70 \mathrm{Ha}$. Nilai basis tanaman tebu di kecamatan Tembelang lebih dipengaruhi dari tidak adanya produksi tanaman perkebunan lain. Menurut data BPS Kabupaten Jombang dari tahun 2014-2018 produksi tanaman perkebunan lain yang ada di kecamatan Tembelang tercatat hanya terdapat kelapa pada tahun 2014-2017.

Kecamatan Kesamben merupakan basis produksi serta luas lahan tanaman tebu di kabupaten Jombang pada tahun 2014-2018. Kecamatan Kesamben memiliki rata-rata nilai produksi tanaman tebu sebesar 186.703,93 ton dengan nilai $L Q 2,52$ dan rata-rata luas lahan 128.985,23 Ha dengan nilai $L Q$ 1,61. Penggunaan luas lahan di kecamatan Kesamben mayoritas digunakan untuk sektor tanaman pangan dan sedikit untuk tanaman perkebunan. Perhitungan nilai basis di kecamatan Kesamben dipengaruhi oleh tanaman tebu merupakan tanaman perkebunan unggulan yang ada di wilayah tersebut.

Kecamatan Kudu bukan merupakan basis produksi serta luas lahan tanaman tebu di kabupaten Jombang pada tahun 2014-2018. Kecamatan Kudu memiliki rata-rata nilai produksi tanaman tebu sebesar $104.277,40$ ton dengan nilai $L Q \quad 0,81$ dan rata-rata luas lahan $70.865,83 \mathrm{Ha}$ dengan nilai $L Q \quad 0,74$. Walaupun kecamatan Kudu memiliki angka produksi dan luas lahan yang cukup besar untuk tanaman tebu, nilai LQ tanaman tebu dipengaruhi oleh produksi dan luas lahan tanaman tembakau yang lebih besar di wilayah tersebut.

Kecamatan Ngusikan merupakan basis produksi serta luas lahan tanaman tebu di Kabupaten Jombang pada tahun 2014-2018. Kecamatan Ngusikan memiliki rata-rata nilai produksi tanaman tebu sebesar 139.702,64 ton dengan nilai $L Q 1,46$ dan rata-rata luas lahan 106.499,35 Ha dengan nilai LQ 1,05. Nilai LQ tanaman tebu di Kecamatan Ngusikan dipengaruhi oleh besarnya produksi dan luas lahan tanaman tebu itu sendiri. Kecamatan Ngusikan memiliki persaingan dalam produksi dan luas lahan sektor perkebunan semusim yaitu tanaman tebu dan tembakau, meskipun saling bersaing namun pada tahun 20142018 kedua tanaman tersebut sama-sama memiliki nilai basis di wilayah tersebut.

Kecamatan Ploso pada tahun 2014-2018 bukan merupakan basis produksi serta luas lahan tanaman tebu di Kabupaten Jombang. Kecamatan Ploso memiliki rata-rata nilai produksi tanaman tebu sebesar $27.448,79$ ton dengan nilai $L Q \quad 0,52$ dan rata-rata luas lahan 18.126,88 Ha dengan nilai LQ 0,33 . Nilai LQ tanaman tebu di Kecamatan Ploso dipengaruhi oleh kecilnya produksi dan luas lahan serta kalah bersaing dengan produksi dan luas lahan tanaman tembakau yang lebih unggul di wilayah tersebut.

Kecamatan Kabuh bukan merupakan basis produksi serta luas lahan tanaman tebu di Kabupaten Jombang pada tahun 2014-2018. Kecamatan Kabuh memiliki rata-rata nilai produksi tanaman tebu sebesar 41.676,21 ton dengan nilai LQ 0,44 dan rata-rata luas lahan 17,254.46 Ha dengan nilai LQ 0,25. Kecamatan Kabuh mempunyai nilai basis baik produksi dan luas lahan di kabupaten Jombang pada tahun 2014-2018. Hal tersebut disebabkan oleh besarnya produksi tembakau dibanding tanaman tebu di wilayah tersebut.

Kecamatan Plandaan merupakan basis produksi serta luas lahan tanaman tebu di kabupaten Jombang pada tahun 2014-2018. Kecamatan Plandaan memiliki rata-rata nilai produksi tanaman tebu sebesar $26.105,71$ ton dengan nilai LQ 0,65 dan rata-rata luas lahan 12.544,64 $\mathrm{Ha}$ dengan nilai LQ 0,52 . 
Nilai LQ tanaman tebu di kecamatan Ploso dipengaruhi oleh kecilnya produksi dan luas lahan serta kalah bersaing dengan produksi dan luas lahan tanaman tembakau yang lebih unggul di wilayah tersebut.

Tabel 3. Nilai LQ Tanaman Tembakau menurut Produksi dan Luas Lahan di Kabupaten Jombang Tahun 2014-2018

\begin{tabular}{|c|c|c|c|c|c|c|c|c|c|c|}
\hline \multirow{3}{*}{ Kecamatan } & \multicolumn{10}{|c|}{ Nilai LQ Tembakau } \\
\hline & \multicolumn{5}{|c|}{ Produksi (ton) } & \multicolumn{5}{|c|}{ Luas Lahan (Ha) } \\
\hline & 2014 & 2015 & 2016 & 2017 & 2018 & 2014 & 2015 & 2016 & 2017 & 2018 \\
\hline BK. Mulyo & - & - & - & - & - & - & - & - & - & - \\
\hline Perak & - & - & - & - & - & - & - & - & - & - \\
\hline Gudo & - & - & - & - & - & - & - & - & - & - \\
\hline Diwek & - & - & - & - & - & - & - & - & - & - \\
\hline Ngoro & - & - & - & - & - & - & - & - & - & - \\
\hline Mojowarno & - & - & - & - & - & - & - & - & - & - \\
\hline Bareng & - & 0,03 & 0,03 & 0,15 & 0,01 & - & 0,03 & 0,04 & 0,03 & 0,03 \\
\hline Wonosalam & - & - & - & - & - & - & - & - & - & - \\
\hline Mojoagung & - & - & - & - & - & - & - & - & - & - \\
\hline Sumobito & - & - & - & - & - & - & - & - & - & - \\
\hline Jogoroto & - & - & - & - & - & - & - & - & - & - \\
\hline Peterongan & - & - & - & - & - & - & - & - & - & - \\
\hline Jombang & - & - & - & - & - & - & - & - & - & - \\
\hline Megaluh & - & - & - & - & - & - & - & - & - & - \\
\hline Tembelang & - & - & - & - & - & - & - & - & - & - \\
\hline Kesamben & - & - & - & - & - & - & - & - & - & - \\
\hline Kudu & 2,67 & 3,92 & 7,50 & 1,11 & 4,99 & 2,12 & 2,33 & 6,17 & 1,99 & 2,36 \\
\hline Ngusikan & 3,31 & 4,67 & 0,64 & 0,66 & 0,20 & 2,68 & 2,98 & 0,73 & 0,30 & 0,70 \\
\hline Ploso & 14,18 & 6,41 & 16,82 & 1,16 & 18,73 & 3,47 & 3,07 & 20,32 & 3,23 & 2,88 \\
\hline Kabuh & 12,55 & 11,87 & 35,91 & 1,16 & 26,22 & 3,52 & 3,98 & 49,06 & 3,30 & 2,96 \\
\hline Plandaan & 4,23 & 10,20 & 9,75 & 1,14 & 10,50 & 2,45 & 3,01 & 13,16 & 2,60 & 2,68 \\
\hline
\end{tabular}

Tabel 4. Rata-Rata Produksi, Luas Lahan dan Nilai LQ Tanaman Tembakau di Kabupaten Jombang Tahun 2014-2018

\begin{tabular}{lcc|cc}
\hline \multirow{2}{*}{ Kecamatan } & \multicolumn{4}{c}{ Rata-Rata Produksi, Luas Lahan \& LQ Tembakau } \\
\cline { 2 - 5 } & $\begin{array}{c}\text { Produksi } \\
\text { (ton) }\end{array}$ & $\begin{array}{c}\text { LQ } \\
\text { Produksi }\end{array}$ & $\begin{array}{c}\text { Luas Lahan } \\
\text { (Ha) }\end{array}$ & $\begin{array}{c}\text { LQ } \\
\text { Luas Lahan }\end{array}$ \\
\hline B. Kedung Mulyo & - & - & - & - \\
Perak & - & - & - & - \\
Gudo & - & - & - & - \\
Diwek & - & - & - & - \\
Ngoro & - & - & - & - \\
Mojowarno & - & - & - & - \\
Bareng & 106 & 0,05 & 10,60 & 0,02 \\
Wonosalam & - & - & - & - \\
Mojoagung & - & - & - & - \\
Sumobito & - & - & - & -
\end{tabular}




\begin{tabular}{lcc|cc} 
Jogoroto & - & - & - & - \\
Peterongan & - & - & - & - \\
Jombang & - & - & - & - \\
Megaluh & - & - & - & - \\
Tembelang & - & - & - & - \\
Kesamben & - & - & - & 2,99 \\
Kudu & 9,300 & 4,04 & 704,60 & 1,48 \\
Ngusikan & 4,924 & 1,90 & 514,40 & 6,60 \\
Ploso & 9,809 & 11,46 & 829,80 & 12,57 \\
Kabuh & 23,483 & 17,54 & $2,219,60$ & 4,78 \\
Plandaan & 6,850 & 7,16 & 407,20 & \\
\hline
\end{tabular}

Sumber : Data diolah, 2020

Teknologi budidaya tembakau madura rendah nikotin sesuai untuk lahan kering dengan ketinggian tempat 50-350 mdpl. Lahan-lahan tersebut merupakan sentra tembakau madura yang berjenis tanah Mollisol (Benzina) dan Alfisol (Mediteran). Pada umumnya lahan-lahan tersebut bertekstur tanah lempung dan lempung berpasir. Sentra-sentra produksi tembakau madura yang sesuai dengan teknologi budidaya tembakau rendah nikotin adalah daerah dengan tipe iklim $C$ dan $D$, dengan curah hujan rata-rata 940-1.373 mm/tahun, yang mempunyai jumlah bulan basah 4-6 bulan dan jumlah bulan kering 5-6 bulan (Balittas litbang pertanian, tahun 2004).

Berdasarkan tabel 3 dan 4 diketahui bahwa Kecamatan Bareng memiliki produksi dan luas lahan pada tahun 2014-2018, akan tetapi bukan merupakan basis produksi dan luas lahan di kabupaten Jombang. Kecamatan Bareng mempunyai rata-rata nilai produksi tanaman tembakau sebesar 106 ton dengan nilai LQ 0,05 dan rata-rata luas lahan $10,60 \mathrm{Ha}$ dengan nilai LQ 0,02 . Nilai LQ tanaman tembakau di kecamatan Bareng dipengaruhi oleh rendahnya angka produksi dan luas lahan di wilayah tersebut di bandingkan kecamatan lain di kabupaten Jombang. Angka produksi dan luas lahan untuk tanaman tembakau terus mengalami penurunan dari tahun 2015-2018. Penurunan angka tersebut dipengaruhi oleh kondisi lahan pertanian dan pengairan di kecamatan Bareng. Menurut BPS Kabupaten Jombang Kecamatan Bareng Dalam Angka Tahun 2019, Kecamatan Bareng hanya memiliki $10 \mathrm{Ha}$ lahan sawah tadah hujan yang terletak di desa Jenis Gelaran. Analisa tersebut sejalan dengan laporan Dwiratna (2016) dari hasil riset dimana sebagian besar petani pemilik lahan sawah tadah hujan lebih memilih menanam tembakau atau jagung pada saat periode musim tanam kemarau.

Kecamatan Kudu merupakan basis produksi dan luas lahan tanaman tembakau pada tahun 2014-2018 di Kabupaten Jombang. Kecamatan tersebut mempunyai rata-rata nilai produksi tanaman tembakau sebesar 9.300 ton dengan nilai LQ 4,04 dan rata-rata luas lahan 704,60 Ha dengan nilai LQ 2,99. Berdasarkan data BPS Kabupaten Jombang, Kecamatan Kudu Dalam Angka Tahun 2019, kecamatan Kudu memiliki luas lahan tadah hujan dengan total $599,60 \mathrm{Ha}$. Luas lahan tadah hujan tersebut berada di Desa Bakalanrayung dengan 39,23 Ha, Sumberteguh 112,03 Ha, Made $156 \mathrm{Ha}$, Kepuhrejo $94 \mathrm{Ha}$, Bendungan 44,02 Ha dan Katemas dengan 114,32 Ha.

Kecamatan Ngusikan pada tahun 2014-2018 merupakan basis produksi dan luas lahan tanaman tembakau di kabupaten Jombang. Kecamatan Ngusikan memiliki rata-rata nilai produksi tanaman tembakau sebesar 9.300 ton dengan nilai LQ 1,90 dan rata-rata luas lahan $514.40 \mathrm{Ha}$ dengan nilai LQ 1,48. Luas 
lahan sawah tadah hujan di kecamatan Ngusikan mencapai 450,56 Ha. Meskipun memiliki persaingan dalam produksi dan luas lahan dengan tanaman tebu, namun kedua sektor tersebut mampu menjadi tanaman unggulan di kecamatan Ngusikan

Kecamatan Ploso merupakan basis produksi dan luas lahan tanaman tembakau pada tahun 2014-2018 di kabupaten Jombang. Kecamatan Ploso mempunyai rata-rata nilai produksi tanaman tembakau sebesar 9.809 ton dengan nilai $L Q 11,46$ dan rata-rata luas lahan 829,80 Ha dengan nilai $L Q 6,60$. Berdasarkan data BPS Kabupaten Jombang Kecamatan Ploso Dalam Angka Tahun 2019, kecamatan Ploso mempunyai luas lahan sawah tadah hujan 1.103,8 Ha. Besarnya luas lahan tadah hujan di kecamatan tersebut digunakan para petani dalam berbudidaa tanaman tembakau.

Produksifitas tanaman tembakau di kabupaten Jombang terbesar berada di wilayah utara sungai Brantas yang meliputi : kecamatan Plandaan, Kecamatan Kabuh, Kecamatan Ploso, Kecamatan Kudu dan Kecamatan Ngusikan. Wilayah utara sungai brantas memiliki karakteristik lahan tadah hujan dimana saat musim penghujan lahan sawah digunakan untuk tanam padi, sedangkan saat musim kemarau lahan sawah digunakan untuk bertanam tembakau atau jagung. Kecamatan Kabuh merupakan basis produksi dan luas lahan tanaman tembakau pada tahun 2014-2018 di kabupaten Jombang. Kecamatan tersebut memiliki rata-rata nilai produksi tanaman tembakau sebesar 23.483 ton dengan nilai LQ 17,54 dan rata-rata luas lahan 2.219,60 Ha dengan nilai LQ 12,57. Kecamatan Kabuh menjadi basis produksi dan luas lahan tanaman tembakau terbesar dibandingkan dengan kecamatan lain yang ada di kabupaten Jombang.

Kecamatan Plandaan pada tahun 2014-2018 merupakan basis produksi dan luas lahan tanaman tembakau di kabupaten Jombang. Kecamatan Plandaan memiliki rata-rata nilai produksi tanaman tembakau sebesar 6.850 ton dengan nilai LQ 7,12 dan rata-rata luas lahan 407,20 Ha dengan nilai LQ 4,78. Walaupun mempunyai angka nilai basis lebih besar daripada kecamatan Kudu, produksi dan luas lahan tanaman tembakau di kecamatan Plandaan tidaklah lebih besar dari kecamatan Kudu. Nilai basis di kecamatan Plandaan dipengaruhi oleh persaingan antar tanaman perkebunan lain di wilayah tersebut, dimana tanaman tembakau dapat mengungguli produktifitas tanaman tebu di perhitungan nilai LQ.

\section{KESIMPULAN}

Berdasarkan perhitungan hasil nilai location quotient (LQ) serta identifikasi faktor yang mempengaruhi dapat disimpulkan sebagai berikut :

1. Produksi tanaman tebu menurut perhitungan $L Q$ menunjukkan bahwa tanaman tebu yang mempunyai nilai basis produksi di kabupaten Jombang pada tahun 2014-2018 adalah kecamatan Bandar Kedung Mulyo, Perak, Gudo, Diwek, Ngoro, Mojowarno, Bareng, Wonosalam, Mojoagung, Sumobito, Peterongan, Jombang, Jogoroto, Peterongan, Tembelang, Megaluh, Kesamben dan Ngusikan.

2 Luas lahan tanaman tebu menurut perhitungan $L Q$ menunjukkan bahwa luas lahan tanaman tebu pada tahun 2014-2019 di kabupaten Jombang yang mempunyai nilai luas lahan tebu sebagai sektor basis ekonomi adalah kecamatan Bandar Kedung Mulyo, Perak, Gudo, Diwek, Ngoro, Mojowarno, Bareng, Mojoagung, Sumobito, Peterongan, Jombang, Jogoroto, Peterongan, Tembelang, Megaluh, Kesamben dan Ngusikan.

3. Produksi tanaman tembakau menurut perhitungan $L Q$ menunjukkan bahwa tanaman tembakau yang memiliki nilai basis produksi di kabupaten Jombang 
pada tahun 2014-2018 adalah Kudu, Ngusikan, Ploso, Kabuh dan Plandaan.

4. Luas lahan tanaman tembakau menurut perhitungan $L Q$ menunjukkan bahwa luas lahan tanaman tembakau pada tahun 2014-2019 di kabupaten Jombang yang memiliki nilai luas lahan sebagai sektor basis adalah kecamatan Kudu, Ngusikan, Ploso, Kabuh dan Plandaan.

\section{DAFTAR PUSTAKA}

Agung Ridho Pratama, Ketut Sukiyono dan Nyayu Neti Arianti. 2017. Analisis Subsektor Pertanian Unggulan Kabupaten/Kota di Provinsi Bengkulu. Fakultas Pertanian Universitas Bengkulu.

Balai Penelitian Tanaman Pemanis dan Serat. Budidaya Tanaman Tembakau Rendah Nikotin. diakses melalui http://balittas.litbang.pertanian.go.id/index.php/id/resource/sdm-peneliti/38penelitian/hasil-penelitian/163-tembakau-madura pada tanggal 4 Oktober 2020

Badan Pusat Statistik. 2018. Produksi Perkebunan Tebu Menurut Kabupaten/Kota di Jawa Timur Tahun 2006-2017.

Badan Pusat Statistik.2018. Produksi Perkebunan Tembakau Menurut Kabupaten / Kota di Jawa Timur Tahun 2006-2015.

BPS Provinsi Jawa Timur. 2018. Produksi Perkebunan Tebu Menurut Kabupaten/Kota di Jawa Timur Tahun 2013-2017 (Ton).

Dinas Pertanian Pertanian Kabupaten Pasuruan. 2013. Budidaya Tanaman Tebu.

Ilham Alkaf. 2015. Peran Sektor Pertanian Terhadap Perekonomian Kabupaten Cilacap Periode 2002-2013: Dengan Pendekatan Tipologi Klassen, Shift Share, dan Loqation Quetient. Jakarta. Fakultas Sains dan Teknologi UIN Syarif Hidayatullah.

Tanjung. I.P 2017. Kontribusi Subsektor Perkebunan Terhadap Perekonomian Daerah : Studi Kasus di Provinsi Jawa Timur. Jurusan Ekonomi Pembangunan, Fakultas Ekonomi dan Bisnis Universitas Islam Negeri Syarif Hidayatullah Jakarta.

M Erwin Hidayat dan Rimadewi Supriharjo. 2004. Identifikasi Sub Sektor Unggulan Kecamatan di Kabupaten Lombok Tengah. Jurnal Teknik ITS

Sumitro Djojohadikusumo. 1991. Perkembangan Pemikiran Ekonomi. Jakarta. Yayasan Obor Indonesia.

Tjokrowinoto Moeljarto. 2004. Pembangunan Dilema Dan Tantangan. Yogyakarta. Pustaka Pelajar.

Tarigan, Robinson. 2007. Ekonomi Regional, Teori dan Aplikasi. Jakarta. PT. Bumi Aksara, Cetakan Keempat. 
SigmAgri (Journal of Social, Management, and Agribusiness)

Volume 01 No 01

Sitti Hawa. 2018. Analisis Sektor Basis Dan Posisi Sektor Ekonomi Kabupaten Pangkajene Dan Kepulauan Periode 2011-2015. Jurusan Ilmu Eknonomi Fakultas Ekonomi dan Bisnis Islam UIN Alauddin Makassar

Dwiratna,S 2016. Optimalisasi Pola Tanam Pada Lahan Sawah Tadah Hujan di Kecamatan Cimanggung Kabupaten Sumedang. Jurnal Departemen Teknik Pertanian dan Biosistem FTIP Universitas Padjajaran. 